\title{
Detection of foot-and-mouth disease virus rna by reverse transcription loop-mediated isothermal amplification
}

\author{
Hao-tai Chen ${ }^{\dagger}$, Jie Zhang ${ }^{\dagger}$, Yong-sheng Liu ${ }^{*}$ and Xiang-tao Liu*
}

\begin{abstract}
A reverse transcription loop-mediated isothermal amplification (RT-LAMP) assay was developed for foot-and-mouth disease virus (FMDV) RNA. The amplification was able to finish in 45 min under isothermal condition at $64^{\circ} \mathrm{C}$ by employing a set of four primers targeting FMDV 2B. The assay showed higher sensitivity than RT-PCR. No cross reactivity was observed from other RNA viruses including classical swine fever virus, swine vesicular disease, porcine reproductive and respiratory syndrome virus, Japanese encephalitis virus. Furthermore, the assay correctly detected 84 FMDV positive samples but not 65 FMDV negative specimens. The result indicated the potential usefulness of the technique as a simple and rapid procedure for the detection of FMDV infection.
\end{abstract}

Keywords: Foot-and-mouth disease virus, Detection, Reverse transcription loop-mediated isothermal amplification, Sensitivity, Specificity

\section{Background}

Foot-and-mouth disease virus (FMDV) is a member of the genus Aphthovirus of the family Picornaviridae, which is divided into seven serotypes with no cross-protection conferred among the serotypes [1]. Due to the aggressive nature of foot-and-mouth disease (FMD), outbreaks usually result in severe economic losses and impact on both national and international trade within the livestock and animal products [2]. Rapid and accurate diagnosis of any suspected FMD cases is of utmost urgency to control this veterinary infection given the extreme contagiousness of the causative virus.

Conventional laboratory diagnosis of FMD was made by ELISA detection of specific viral antigens and by observation of cytopathic effects in cell culture [3]. Alternatively, the conventional reverse transcriptase polymerase chain reaction (RT-PCR) [4] and real-time RT-PCR $[2,5]$ were developed to complement primary diagnostic techniques for the FMDV infection. These

\footnotetext{
*Correspondence: liuyongshengvip8@163.com; hnxiangtao@hotmail.com † Contributed equally

State Key Laboratory of Veterinary Etiologic Biology, National Foot-andMouth Disease Reference Laboratory of China, Key laboratory of Animal Virology of Ministry of Agriculture, Lanzhou Veterinary Research Institute, Chinese Academy of Agricultural Sciences, Lanzhou, 730046, Gansu, P.R.
} China

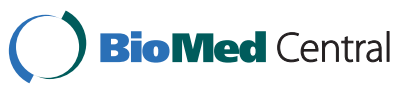

(C) 2011 Chen et al; licensee BioMed Central Ltd. This is an Open Access article distributed under the terms of the Creative Commons Attribution License (http://creativecommons.org/licenses/by/2.0), which permits unrestricted use, distribution, and reproduction in any medium, provided the original work is properly cited. assays were time-consuming and laborious, which required centralized laboratory facilities and clinical specimen submissions, resulted in the delay of FMDV diagnosis. Given these problems, a rapid, simple and practical assay to detect FMDV in animal and its products was therefore required in clinical practice.

A reverse transcription loop-mediated isothermal amplification (RT-LAMP) was applied successfully to the detection of many animal viruses [6-9]. In this study, we evaluated the potential of RT-LAMP for the development of a simple and rapid detection system for

\section{Materials and methods}

\subsection{Viral strains and samples}

The strains O/CHA/1999, A/CHA/2009, C/SU/1958, Asia 1/CHA/2005 were developed RT-LAMP method and then the stain O/CHA/1999 was to test the detection limit. The serotypes $\mathrm{O}$ and Asia 1 were propagated in IBRS-2 cells, and the serotypes A and C were inoculated in 3-day suckling mice, respectively.

Other field isolates including classical swine fever virus (CSFV), swine vesicular disease virus (SVDV), porcine reproductive and respiratory syndrome virus FMDV RNA. 
Table 1 Result comparison of RT-LAMP and RT-PCR assays using 139 samples

\begin{tabular}{llll}
\hline Pathogen & Strain (specimen number) & \multicolumn{2}{l}{ Results (positive number/specimen number tested) } \\
\cline { 2 - 4 } & & RT-LAMP & RT-PCR \\
\hline FMDV & O/CHA/1999 $(\mathrm{N}=32)$ & $+(32 / 32)$ & $+(32 / 32)$ \\
& $\mathrm{A} / \mathrm{CHA} / 2009(\mathrm{~N}=22)$ & $+(22 / 22)$ & $+(20 / 20)$ \\
& Asia $1 / \mathrm{CHA} / 2005(\mathrm{~N}=20)$ & $+(20 / 20)$ & $+(10 / 10)$ \\
CSFV & $\mathrm{C} / \mathrm{N} / 1988(\mathrm{~N}=10)$ & $+(10 / 10)$ & $-(17 / 17)$ \\
SVDV & C2008 $(\mathrm{N}=17)$ & $-(17 / 17)$ & $-(10 / 10)$ \\
PRRSV & SVDV01 $(\mathrm{N}=10)$ & $-(10 / 10)$ & $-(19 / 19)$ \\
JEV & HPBEDV $(\mathrm{N}=19)$ & $-(19 / 19)$ & $-(9 / 9)$ \\
\hline
\end{tabular}

+ , positive reaction; - , negative reaction

(PRRSV) and Japanese encephalitis virus (JEV) were identified by RT-PCR.

A total of 139 samples included 84 FMDV, 17 CSFV, 10 SVDV, 19 PRRSV and 9 JEV specimens, which were also identified by RT-PCR (Table 1).

\subsection{RNA extraction}

RNA was extracted from FMDV-infected and healthy animals, using a RNeasy Mini Kit (Qiagen) according to the manufacturer's instructions. After extraction, RNA was eluted in $60 \mu \mathrm{l}$ of elution buffer and stored at $-20^{\circ} \mathrm{C}$.

\subsection{Conventional RT-PCR and RT-LAMP}

The detection of FMDV by RT-PCR was performed with primers described previously [10]. A set of four primers, $\mathrm{F}, \mathrm{B}$, FIP and BIP were designed by targeting conserved regions of FMDV 2B (Table 2). 2B nucleotide sequences of all the FMDV serotypes were retrieved from GenBank and aligned using the software program DNAStar (DNASTAR, Inc. Madison). The accession numbers used for the alignment were the following: AY593782 (A), AY593801 (A), AY593768 (A), AY593795 (Asia 1), EF149010 (Asia 1), AY593796 (Asia 1), AY593799 (Asia 1), AY593810 (C), AY593806 (C), AY593809 (C), AJ539138 (O), AY593817 (O), AF511039 (O), AY593845 (SAT 1), AY593839 (SAT 1), AY593844 (SAT 1), AY593847 (SAT 2), AY593848 (SAT 2), AY593849

Table 2 Details of RT-LAMP primers designed for detection of 2B coding sequences of FMDV

\begin{tabular}{cc}
\hline Primer name & Sequence \\
\hline F & 5'-CCTGTCGTGCATGGCCGCTGT-3' \\
B & 5'-GAAACACGAGGCAACTTGAC-3' \\
FIP & 5'-CTTACAGACGAAGGTGCTGTC \\
& + \\
& CATCATGCTGGCCGACACCG-3' \\
& 5'-AGATCTCCGACTCGCTCTCCA \\
& + \\
& ACAGGACCGGTGCTCCGAAAC-3' \\
\hline
\end{tabular}

(SAT 2), AY593850 (SAT 3), AY593852 (SAT 3), AY593853 (SAT 3).

RT-LAMP reaction was carried out in a conventional water bath by mixing $2.0 \mu \mathrm{M}$ each of FIP and BIP primer, $0.2 \mu \mathrm{M}$ each of $\mathrm{F}$ and $\mathrm{B}$ primer, $1.0 \mathrm{mM}$ each deoxynucleoside triphosphate, $8 \mathrm{U}$ of Bst DNA polymerase (New England Biolabs) and $1 \mathrm{U}$ of the THERMO-X reverse transcriptase (Invitrogen) using the manufacturer's supplied $10 \times$ buffer (containing $4 \mathrm{mM}$ of $\mathrm{MgSO}_{4}$, $0.8 \mathrm{M}$ betaine) and $1 \mu \mathrm{l}$ of extracted template RNA in a $0.2 \mathrm{ml}$ Eppendorf tube. The amplification was performed at $64^{\circ} \mathrm{C}$ for $45 \mathrm{~min}$ and then terminated by heating at $80^{\circ} \mathrm{C}$ for $10 \mathrm{~min}$. RT-LAMP products were analyzed by $2.5 \%$ agarose gel electrophoresis.

\subsection{Sensitivity and specificity of RT-LAMP for FMDV}

Compared to RT-PCR, the detection limit of RT-LAMP was tested using the same templates at identical concentrations, which was performed in triplicate at each concentration of templates. The O/CHA/1999 RNA was quantitated using UV spectrophotometry (UNICAM 3000, US). Serial dilutions of $1,10,10^{2}, 10^{3}$ and $10^{4}$ copies per reaction from FMDV strains were used in the assay. To assess the specificity of RT-LAMP, cross reactions with RNA of the strains CSFV, SVDV, PRRSV and JEV were examined. Viral RNA of the strains O/CHA/1999, A/CHA/2009, C/SU/1958 and Asia 1/CHA/2005 was used as the positive control and RNA extracted from healthy swine tissues was used as the negative control. In addition, RNA from 139 samples was extracted and subjected to FMDV RT-LAMP.

\section{Results}

3.1. Analysis sensitivity of the LAMP method compared to PCR. Detection limit of FMDV RT-LAMP

The amplification by FMDV RT-LAMP showed a ladder-like pattern (Figure 1). The result indicated that the detection limit of FMDV RT-LAMP was 10 copies whereas that of RT-PCR was 100 copies per reaction. The detection sensitivity of FMDV RT-LAMP was therefore greater than that of RT-PCR. 


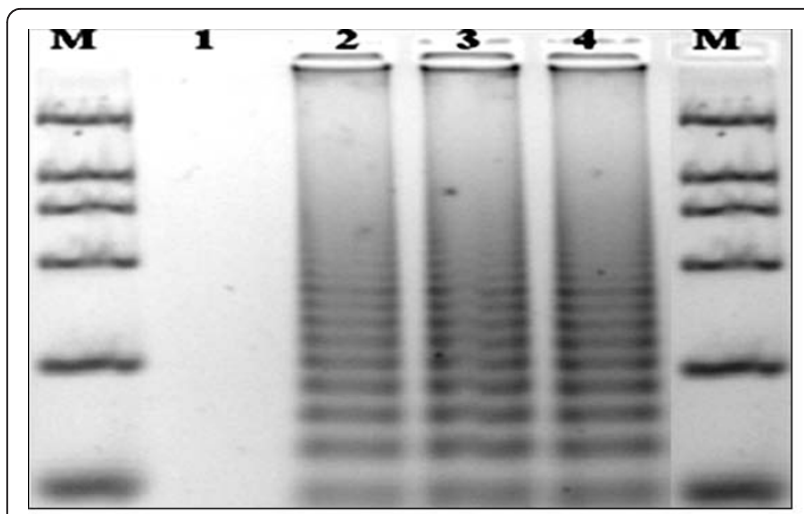

Figure 1 Agarose gel electrophoresis analysis of RT-LAMP products using FMDV reference strains. Lane M, DNA Marker DL2000 (2000, 1000, 750, 500, 250, 100 bp); Lane 1, PRRSV; Lane 2, O/CHA/1999; Lane 3, A/CHA/2009; Lane 4, Asia 1/CHA/2005.

\subsection{Analytical cross reaction of FMDV RT-LAMP}

RNA extracted from tissues of healthy animals and pigs infected with CSFV, SVDV, PRRSV and JEV was used as templates for RT-LAMP. Agarose gel electrophoresis analysis indicated that FMDV RT-LAMP reaction did not detect CSFV, SVDV, PRRSV and JEV as well as gave a negative reaction with tissues of healthy swine, but FMDV RNA was the positive reaction.

\subsection{Evaluation of FMDV RT-LAMP with samples}

To evaluate specificity and sensitivity of FMDV RTLAMP, the assay correctly detected 84 FMDV positive samples but not 65 FMDV negative specimens (Table 1).

\section{Discussion}

For countries to remain FMD-free or to control FMD, rapid and accurate detection of FMDV was played a critical role in the implementation of effective countermeasures to control spread of FMD. RT-LAMP was a sensitive diagnostic method, which was quite simple, requiring only a conventional water bath or heat block for incubation under isothermal conditions [7-9]. Another useful feature of RT-LAMP is that its products can be observed directly by naked eye, because a white precipitate of magnesium pyrophosphate forms in the reaction tube [11]. Adding SYBR Green I to RT-LAMP reactions can also increase the ease detection by the naked eye [12].

Unlike RT-PCR, the greater sensitivity and specificity of RT-LAMP were reported to utilize to detect animal viruses $[7,8]$. The lack of cross reaction observed with CSFV, SVDV, PRRSV and host-derived RNA indicated that FMDV RT-LAMP assay was specific in addition to high sensitivity. In addition, the serotypes SAT1, SAT2 and SAT3 were not investigated in the present study due to absence of those strains or the positive clinical samples in our reference laboratory. Nevertheless, 2B was a highly conserved region in all FMDV serotypes [1], and a set of four primers targeting $2 \mathrm{~B}$ sequence of all serotypes of FMDV were theoretically designed and likely detected seven serotypes of the FMDV infection. However, this speculation will be further indicated in the future.

RT-LAMP was a simple and timesaving procedure, allowing results to be obtained within 1 hour, whereas RT-PCR method typically requires 2 to 4 hours. Compared to RT-PCR, RT-LAMP method was a sensitive tool for the clinical diagnosis of FMDV infection. Nonetheless, the reliability of this assay should be further evaluated by large-scale investigation.

\section{Acknowledgements}

This work was supported in part by grants from the National Key Technologies R\&D Program of China (No. 2006BAD06A03). This study was also supported by the National Natural Science Foundation of China (No. 31172335, No. 30700597 and No. 31072143).

\section{Authors' contributions}

HTC and JZ designed the research, and carried out most of the experiments. XTL supported experiments. HTC and YSL wrote and revised the manuscript. All of the authors approved the final version of the manuscript.

\section{Competing interests}

The authors declare that they have no competing interests.

Received: 19 July 2011 Accepted: 9 November 2011

Published: 9 November 2011

\section{References}

1. Carrillo C, Tulman ER, Delhon G, Lu Z, Carreno A, Vagnozzi A, Kutish GF, Rock DL: Comparative genomics of foot-and-mouth disease virus. J Virol 2005, 79(10):6487-504

2. King DP, Ferris NP, Shaw AE, Reid SM, Hutchings GH, Giuffre AC, Robida JM, Callahan JD, Nelson WM, Beckham TR: Detection of foot-and-mouth disease virus: comparative diagnostic sensitivity of two independent real-time reverse transcription-polymerase chain reaction assays. J Vet Diagn Invest 2006, 18:93-97.

3. Alexandersen Z, Zhang Al, Donaldson, Garland AJ: The pathogenesis and diagnosis of foot-and-mouth disease. J Comp Pathol 2003, 129:1-36.

4. Reid SM, Ferris NP, Hutchings GH, Samuel AR, Knowles NJ: Primary diagnosis of foot-and-mouth disease by reverse transcription polymerase chain reaction. J Virol Methods 2000, 89:167-176.

5. Reid SM, Ferris NP, Hutchings GH, Zhang Z, Belsham GJ, Alexandersen S: Detection of all seven serotypes of foot-and-mouth disease virus by real-time, fluorogenic reverse transcription polymerase chain reaction assay. J Virol Methods 2002, 105:67-80.

6. Chen HT, Zhang J, Ma LN, Ma YP, Ding YZ, Liu XT, Chen L, Ma LQ, Zhang YG, Liu YS: Rapid pre-clinical detection of classical swine fever by reverse transcription loop-mediated isothermal amplification. Mol Cell Probes 2009, 23(2):71-74.

7. Chen HT, Zhang J, Ma YP, Ma LN, Ding YZ, Liu XT, Cai XP, Ma LQ, Zhang YG, Liu YS: Reverse transcription loop-mediated isothermal amplification for the rapid detection of infectious bronchitis virus in infected chicken tissues. Mol Cell Probes 2010, 24(2):104-106.

8. Chen HT, Zhang J, Sun DH, Ma LN, Liu XT, Cai XP, Liu YS: Development of reverse transcription loop-mediated isothermal amplification for rapid detection of $\mathrm{H} 9$ avian influenza virus. J Virol Methods 2008, 151(2):200-203.

9. Chen HT, Zhang J, Sun DH, Ma LN, Liu XT, Quan K, Liu YS: Reverse transcription loop-mediated isothermal amplification for the detection of highly pathogenic porcine reproductive and respiratory syndrome virus. J Virol Methods 2008, 153(2):266-268. 
10. Fernandez J, Aguero M, Romero L, Sanchez C, Belak S, Arias M, SanchezVizcaino JM: Rapid and differential diagnosis of foot-and-mouth disease, swine vesicular disease, and vesicular stomatitis by a new multiplex RTPCR assay. J Virol Methods 2008, 147:301-311.

11. Mori Y, Nagamine K, Tomita N, Notomi T: Detection of loop-mediated isothermal amplification reaction by turbidity derived from magnesium pyrophosphate formation. Biochem Biophys Res Commun 2001, 289:150-154.

12. Iwamoto T, Sonobe T, Hayashi K: Loop-Mediated Isothermal Amplification for Direct Detection of Mycobacterium tuberculosis Complex, M. avium, and M intracellulare in Sputum Samples J Clin Microbiol 2003, 41:2616-2622.

doi:10.1186/1743-422X-8-510

Cite this article as: Chen et al:. Detection of foot-and-mouth disease virus rna by reverse transcription loop-mediated isothermal amplification. Virology Journal 2011 8:510.

\section{Submit your next manuscript to BioMed Central} and take full advantage of:

- Convenient online submission

- Thorough peer review

- No space constraints or color figure charges

- Immediate publication on acceptance

- Inclusion in PubMed, CAS, Scopus and Google Scholar

- Research which is freely available for redistribution

Submit your manuscript at www.biomedcentral.com/submit 